\title{
Knowledge, Awareness, and Attitudes toward Umbilical Cord Blood Biobanking
}

\author{
Nevenka Kregar Velikonja ${ }^{1,2 *}$ (D), Karmen Erjavec ${ }^{1}$ (D), Miomir Knezevic ${ }^{2}$ (D) \\ ${ }^{1}$ Department of Social Sciences, Faculty of Health Sciences, University of Novo Mesto, Novo Mesto, Slovenia; ${ }^{2}$ Educell, Cell \\ Therapy Company, Trzin, Slovenia
}

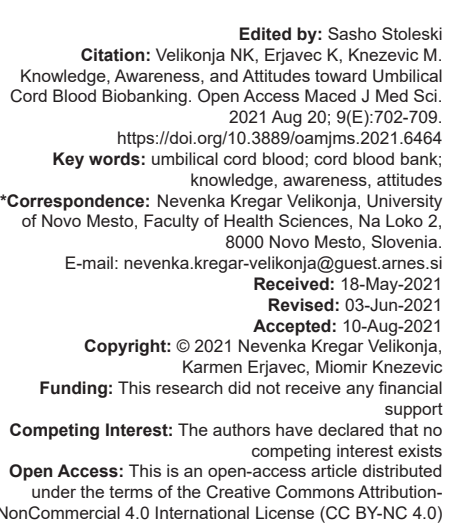

Edited by: Sasho Stoleski

Citation: Velikonja NK, Erjavec K, Knezevic M. Knowledge, Awareness, and Attitudes toward Umbilical Cord Blood Biobanking. Open Access Maced J Med Sci.
2021 Aug 20; $9(E): 702-709$. https://doi.org/10.3889/oamjms.2021.6464 Key words: umbilical cord blood; cord blood bank; knowledge, awareness, attitudes
Correspondence: Nevenka Kregar Velikonja, University of Novo Mesto, Faculty of Health Sciences, Na Loko 2 E-mail: nevenka.kregar-velikonja@guest.arnes.s Received: 18-May-202 Revised: 03-Jun-202 Accepted: 10-Aug-202 Copyright: ๑ 2021 Nevenka Kregar Velikonja, armen Erjavec, Miomir Knezevic Funding: This research did not receive any financial Competing Interest: The authors have declared that no competing interest exists Open Access: This is an open-access article distribute onCommercial 4.0 International License (CC BY-NC 4.0)

\begin{abstract}
BACKGROUND: Umbilical Cord Blood (UCB) stem cells are a non-invasive, effective alternative source of hematopoietic stem cells for the treatment of a variety of diseases.

AIM: The aim of the study was to research knowledge, awareness, and attitudes of the general public and health professionals regarding the UCB storage.

MATERIALS AND METHODS: A cross-sectional study was conducted with an online survey $(n=408)$ using the snowball method.

RESULTS: A majority of respondents declared that they were not aware of UCB banking; however, people with an academic background in healthcare have a greater awareness of UCB banking. A subjective assessment found that their knowledge of UCB banking is better than that of non-professionals, however, they exhibited better knowledge and understanding of UCB use and banking in only a few aspects. People with an academic background in healthcare have a more polarized attitude toward cord blood banking and a higher percentage are unwilling to pay for UCB banking services. However, their preferences regarding public/private UCB banking do not differ significantly from those of non-professionals.
\end{abstract}

CONCLUSION: Here, we show that there is not much difference between the laic and professional categories in terms of knowledge about the specific purpose and characteristics of UCB storage.

\section{Introduction}

Since the first public umbilical cord blood (UCB) bank was founded at the New York Blood Center in the early 1990s [1], UCB banking has spread rapidly across the world [2]. According to World Marrow Donor Association [3], there are currently more than 790,000 frozen UCB units held in more than 160 public UCB banks worldwide.

There are also more than 220 private UCB banks worldwide holding 4 to 5 million samples [4]. Whereas public UCB banks operate at national level only, private UCB banks often operate internationally. Unlike public banks, which mainly store UCB, many private banks also collect and store UCT [5]. Public UCB banks procure, process, test, store, and release blood samples donated for allogeneic use at no cost to the donating parents, while private UCB banks charge a fee to collect, process, and store an infant's UCB and/or UCT for autologous or allogeneic family use [5]. There are also other models, such as family-managed or hybrid public-private banking. The hybrid model aims to merge the potential of publicsector allogeneic storage with the potential application of autologous storage in specific fields of regenerative medicine [6]. Moreover, Hauskeller and Beltrame [2] demonstrated that the interplay of technical, ethical, economic, and logistical considerations, together with the performative role of regulations and the agency of institutional and corporate actors involved produces hybrid configurations of the networks in which UCB circulates. Motives for donating UCB to public UCB banks or for storing tissues in private UCB banks differ and can be influenced by health workers, the media, and other sources of information. An understanding of the attitudes of different segments of the population toward UCB banking can be useful for launching a targeted promotion of UCB donation and biobanking services and for expanding knowledge of its applications.

Awareness of UCB banking by parents and especially by women, who are the main decision makers regarding $U C B$ donation and storage, is crucial to making a reasonable choice about UCB storage [7]. A review of UCB awareness studies found contradictory findings [8]. A number of studies reported a high level of awareness of UCB banking among women [9], [10], [11], while others reported a low level of awareness [7], [12], [13]. Further, knowledge and awareness of UCB banking among health professionals were relatively low [5], [14] despite these health professionals being identified by expectant parents as their preferred, key sources of information [5]. There are no consensus findings on the distribution of sources of knowledge regarding UCB. 
Katz et al. [7] found that a high proportion of women in five European countries (France, Germany, Italy, Spain, and the UK) received their information from midwives and obstetricians. On the other hand, Matijevic and Erjavec [10] found that the main source of information for pregnant women in Croatia was the media, while only a small percentage of pregnant women received their information from their gynecologist and none from other maternity staff members.

Preference studies on UCB storage are rare. According to Peberdy et al. [5], [8], most of the current studies were focused on professionals, donors, pregnant women, or potential parents. There are only a few studies involving general public [9], [13]. The majority of studies reported that personal characteristics, such as age and education, did not matter when evaluating UCB banking. However, Karagiorgou et al. [9] found not only that the majority of randomly selected Greek citizens preferred private to public UCB banks but also that women were more willing to choose a public UCB bank than men. Men were more likely to choose a private bank, regardless of other socio-demographic factors, arguing that UCB would be stored better in a private bank [9]. In addition to altruism, the main reason for donating to public banks was the high costs of private banking [11], [15]. This indirectly shows that ability or willingness to pay is also an important factor in deciding about UCB storage even though no study to date has investigated willingness to pay for UCB storage.

Despite the importance of investigating people's awareness and opinions of autologous UCB banking, we know remarkably little about preferences regarding UCB storage. The decision to use biobanking services or UCB donations depends to a large extent on the perception of the prospects for UCB stem-cell treatment technologies in future, which the reviewed publications did not examine. The investigation of awareness, opinions, knowledge, and preferences regarding UCB storage in Slovenia among health-care professionals and general population in reproductive period is interesting because this country has among the highest rates of reported cellular and engineered tissue therapies per capita [16]. In this Eastern European country with high cell therapy rates and a highly developed system of public and private UCB banking providers, high levels of awareness and knowledge of this topic might be expected.

The aim of this study was to analyze knowledge, awareness, and attitudes of the general public and health professionals regarding the UCB storage.

\section{Methods}

A cross-sectional study applying questionnaire exploring knowledge and awareness of and attitudes toward UCB storage was used to identify opinions on the storage of UCB in Slovenia. A nondiscriminative snowball sampling used in similar studies [17], [18], [19]. The goal of the survey was to reach those segments of the wider population for which cord blood biobanking should be of interest due to their demographic characteristics (mainly general population in reproductive period) or professional interest (health professionals or individuals with an academic background in health sciences and medicine). The initial group of citizens with a high reproductive capacity, as a demographic group that is expected to be well informed about UCB banking, was approached through the main web portal for expecting parents (Nosecka.si) and through the personal contacts of project members. Health professionals working in different sectors of the health system and students of health sciences and medicine were approached through personal contacts. Both categories were asked to share the link with their colleagues. Participants were asked to complete a selfadministrated, structured electronic questionnaire in Slovene language.

Out of 762 respondents 408 met eligibility criteria (non-professionals: General population in reproductive period [18-44 years] or having child; professionals: people with education in health sciences). Answers from respondents whose demographic characteristics did not fit the target groups (no education in health sciences and not in the reproductive period [18-44 years] and without children) were eliminated. In the first group (non-professionals), respondents whose demographic characteristics defined them as potential parents or young parents but without an educational background in health sciences were included for further analysis. In the second group (professionals), respondents with an educational background in health sciences or with professional experience in the health sector were included in the study.

The anonymous and self-completed questionnaire consisted of 16 questions to obtain the following information: (1) Socio-demographic characteristics of respondents (age, sex, level of education, profession, and parental status), (2) respondents' awareness of UCB banks, (3) the subjective assessment of their overall knowledge, (4) attitudes toward UCB banking, (5) willingness to pay, and (6) UCB banking option preferences. The questionnaire was based on previous studies on knowledge, awareness of, and attitudes toward UCB and UCB banking [9], [7], [11], [15]. Respondents' awareness of UCB banks was assessed by asking whether the interviewees know any biobank in Slovenia (yes/no). The subjective assessment of their overall knowledge was measured using rating scale 1-5 (very poor knowledge - very good knowledge). The attitude toward UCB bank was assessed using rating scale 1-5 (absolutely refuse - absolutely accept UCB storage and use). Willingness to pay and UCB banking option 
preferences were assessed using multiple choice questions. Two pre-tests involving five professionals and ten students from different programs were conducted to ensure that the survey was worded appropriately for cultural and professional considerations.

Data were coded and analyzed by SPSS 24.0 using descriptive statistics. Chi-square $\left(\chi^{2}\right)$ tests were used to determine significant differences, subjective assessments of overall knowledge attitudes and preferences, willingness to pay according to demographic characteristics such as gender, age, education, children, and non-professionals/health professionals. The reliability of the questionnaire was tested using Cronbach's coefficient alpha, which had a value of 0.82 , indicating that the measuring instrument was sufficiently reliable.

\section{Results}

There were 408 respondents complying with eligibility criteria, of which $78.7 \%(n=321)$ were female and $21.3 \%(n=87)$ were male. The age of the respondents ranged from 18 to 65 years: $67.4 \%$ $(n=275)$ were aged 18 to 24 years, $25.0 \%$ (102) were aged 25 to 34 years, $3.9 \%(n=16)$ were aged 35 to 44 years, $3.7 \%(n=15)$ were aged 45 years or above. More than one half $(60.0 \%, n=245)$ of the respondents had secondary school education while 30.9\% $(n=126)$ had a graduate or postgraduate degree $9.1 \%(n=37)$. The majority of respondents $(79.7 \% ; n=325)$ had no children, $16.2 \%(n=66)$ had one or more children, and $4.2 \%(n=17)$ were expecting a child.

\section{Awareness}

Only a good quarter of respondents (28.4\%, $n=116$ ) were aware of UCB banking. Their main sources of information were digital media (Internet, social media, forums ...) (21\%) and lectures in schools and university faculties $(21 \%)$, followed by medical health professionals $(15 \%)$, seminars and other forms of professional education $(14 \%)$, leaflets $(9 \%)$, relatives and friends $(6 \%)$, professional colleagues (6\%), and the media (print, TV, radio) $(6 \%)$. There was a significant difference between categories regarding information obtained through the media $(p=0.008)$, where most non-professionals (66.7\%) claimed to have obtained useful information from the mass media rather than from health professionals (33.3\%). More health professionals than non-professionals obtained useful information from faculties $(65.2 \%$ and $34.8 \%$, respectively, $p=0.006)$ and from coworkers ( $p=0.001$ ). Notably, $63.9 \%$ of health professionals and $36.1 \%$ of non-professionals got useful information on UCB banking from colleagues. In all other sources of information, the Chi-square test did not reveal differences between these two categories of participants.
The categories of age, children, education, and non-professionals/professionals demonstrated significant differences regarding awareness of UCB bio banking options in Slovenia in different demographic groups. Most young people under the age of 25 years reported not knowing any Slovenian UCB bank (81.5\%), the awareness was better at higher age groups. Among demographic groups with different levels of education, the percentage of those who knew a Slovenian UCB bank was highest among respondents with a postgraduate degree (70.3\%). According to the parent status, the highest percentage of respondents that knew a Slovenian UCB bank had one or more children $(60.6 \%)$. The percentage of health professionals who knew a Slovenian USB bank was higher (62.9\%) than that of the non-professionals, as shown in Table 1.

Table 1: Awareness about umbilical cord blood banking in Slovenia $(n=408)$

\begin{tabular}{|c|c|c|c|c|}
\hline \multirow[t]{2}{*}{ Category } & \multicolumn{2}{|l|}{$\%(n)$} & \multirow[t]{2}{*}{$x^{2}$} & \multirow[t]{2}{*}{$p$-values } \\
\hline & Yes & No & & \\
\hline \multicolumn{5}{|l|}{ Age } \\
\hline $18-24$ & $18.5 \%(51)$ & $81.5 \%(224)$ & \multirow[t]{4}{*}{46.5} & \multirow[t]{4}{*}{0.001} \\
\hline $25-34$ & $44.1 \%(45)$ & $55.9 \%(57)$ & & \\
\hline $35-44$ & $56.3 \%(9)$ & $43.7 \%(7)$ & & \\
\hline $45-65$ & $73.3 \%(11)$ & $26.7 \%(4)$ & & \\
\hline \multicolumn{5}{|l|}{ Gender } \\
\hline Female & $29.9 \%(96)$ & $70.1 \%(225)$ & \multirow[t]{2}{*}{1.6} & \multirow[t]{2}{*}{0.160} \\
\hline Male & $23.0 \%(20)$ & $77.0 \%(67)$ & & \\
\hline \multicolumn{5}{|l|}{ Level of education } \\
\hline Secondary school & $15.3 \%(38)$ & $84.7 \%(207)$ & \multirow[t]{3}{*}{62.1} & \multirow[t]{3}{*}{0.001} \\
\hline Graduate degree & $41.3 \%(52)$ & $58.7 \%(74)$ & & \\
\hline Postgraduate degree & $70.3 \%(26)$ & $29.7 \%(11)$ & & \\
\hline \multicolumn{5}{|l|}{ Children } \\
\hline None & $20.3(66)$ & $79.7 \%(259)$ & \multirow[t]{3}{*}{51.8} & \multirow[t]{3}{*}{0.001} \\
\hline 1 or more children & $60.6 \%(40)$ & $39.4 \%(26)$ & & \\
\hline Expecting a child & $58.8 \%(10)$ & $41.2 \%(7)$ & & \\
\hline \multicolumn{5}{|l|}{ Health education } \\
\hline Non-professionals & $23.3 \%(77)$ & $77.7 \%(269)$ & \multirow[t]{2}{*}{42.7} & \multirow[t]{2}{*}{0.001} \\
\hline Health professionals & $62.9 \%(39)$ & $37.1 \%(23)$ & & \\
\hline
\end{tabular}

The self-assessment of overall knowledge of UCB banking was low, with a majority $(56 \%, n=228)$ subjectively assessing their level of knowledge as very low or low, and only $18 \%(n=73)$ assessing it as good or very good. There were significant differences in the subjective assessment of knowledge between the categories of age, children, and education. Young people mostly assessed their knowledge as very low $(29.1 \%)$ while other respondents regarded it as average, as shown in Table 2. Respondents with a secondary education mostly assessed their knowledge as very low (29.8\%), others as average. In the education category, the figure was highest for respondents from the postgraduate degree subgroup. Significantly more respondents with one or more children (74.2\%) assessed their knowledge as average or higher, compared to respondents without children or expecting a child. Health professionals mainly assessed their knowledge as average (30.6\%), whereas non-professionals assessed their knowledge as low.

\section{Knowledge of UCB banking}

To assess knowledge of UCB banking, we asked participants about the purpose of UCB storage, 
Table 2: Subjective assessment of the knowledge about umbilical cord blood storage $(n=408)$

\begin{tabular}{|c|c|c|c|c|c|c|c|}
\hline \multirow[t]{2}{*}{ Category } & \multicolumn{5}{|l|}{$\%(\mathrm{n})$} & \multirow[t]{2}{*}{$x^{2}$} & \multirow[t]{2}{*}{$\mathrm{p}$-values } \\
\hline & Very low & Low & Average & Good & Very good & & \\
\hline \multicolumn{8}{|l|}{ Age } \\
\hline $18-24$ & $29.1 \%(80)$ & $28.0 \%(77)$ & $27.6 \%(76)$ & $13.5 \%(37)$ & $1.8 \%(5)$ & \multirow[t]{4}{*}{23.90} & \multirow[t]{4}{*}{0.001} \\
\hline $25-34$ & $15.7 \%(16)$ & $27.5 \%(28)$ & $30.3 \%(31)$ & $16.7 \%(17)$ & $9.8 \%(10)$ & & \\
\hline $35-44$ & $12.5 \%(2)$ & $12.5(2)$ & $25.0 \%(4)$ & $12.5 \%(2)$ & $37.5 \%(6)$ & & \\
\hline $45-65$ & $0 \%(0)$ & $20.0 \%(3)$ & $20.0 \%(3)$ & $33.3 \%(5)$ & $26.7 \%(4)$ & & \\
\hline \multicolumn{8}{|l|}{ Gender } \\
\hline Female & $25.9 \%(83)$ & $24.3 \%(78)$ & $28.3 \%(91)$ & $15.0 \%(21)$ & $6.5 \%(21)$ & \multirow[t]{2}{*}{6.6} & \multirow[t]{2}{*}{0.237} \\
\hline Male & $17.2 \%(15)$ & $36.8 \%(32)$ & $26.5 \%(23)$ & $14.9 \%(13)$ & $4.6 \%(4)$ & & \\
\hline \multicolumn{8}{|l|}{ Level of education } \\
\hline Secondary school & $29.8 \%(73)$ & $28.6 \%(70)$ & $27.3(67)$ & $12.3(30)$ & $2.0(5)$ & \multirow[t]{3}{*}{55.42} & \multirow[t]{3}{*}{0.001} \\
\hline Graduate degree & $17.5 \%(22)$ & $26.2 \%(33)$ & $31.0(39)$ & $18.2 \%(23)$ & $7.1 \%(9)$ & & \\
\hline Postgraduate degree & $8.1 \%(3)$ & $18.9 \%(7)$ & $21.6(8)$ & $29.7 \%(11)$ & 20.00 & & \\
\hline \multicolumn{8}{|l|}{ Children } \\
\hline None & $27.7 \%(90)$ & $28.6 \%(93)$ & $27.1 \%(88)$ & $13.8 \%(45)$ & $2.8 \%(9)$ & \multirow[t]{3}{*}{45.7} & \multirow[t]{3}{*}{0.001} \\
\hline 1 or more children & $7.6 \%(5)$ & $18.2 \%(12)$ & $31.8 \%(21)$ & $21.2 \%(14)$ & $21.2 \%(14)$ & & \\
\hline Expecting a child & $17.6(3)$ & $29.4 \%(5)$ & $29.4 \%(5)^{\prime}$ & $11.8 \%(2)$ & $11.8 \%(2)$ & & \\
\hline \multicolumn{8}{|l|}{ Health education } \\
\hline Non-professionals & $26.3 \%(91)$ & $28.0 \%(97)$ & $27.5 \%(96)$ & $14.7 \%(51)$ & $3.5 \%(12)$ & \multirow[t]{2}{*}{32.4} & \multirow[t]{2}{*}{0.001} \\
\hline Health professionals & $11.3 \%(7)$ & $21.0 \%(13)$ & $30.6 \%(19)$ & $16.1 \%(10)$ & $21.0 \%(13)$ & & \\
\hline
\end{tabular}

the shelf life of stored UCB and whether the procedure of UCB collection after delivery might be dangerous for the mother.

The following were offered as options for the purpose of UCB storage: The potential use of UCB is cloning; treatment of leukemia and other similar diseases; transfusion; treatment of gene diseases; regenerative medicine; and rejuvenation. For each option, participants chose one of the following answers: Definitely not; probably not; probably yes; and definitely yes. There was no significant difference in knowledge between the categories of age, gender, level of education and parental status, as tested with Chi-square. There was a significant difference between the non-professionals and health professionals' categories regarding the storage of UCB for potential cloning $(p=0.029)$, where health professionals were more confident that cloning is not the purpose of UCB storage $(63.9 \%)$ than non-professionals $(50.4 \%)$. Furthermore, health professionals were more confident that $\mathrm{UCB}$ is stored for the potential treatment of leukemia or other similar diseases $(62 \%)$ than nonprofessionals $(47.9 \%)(p=0.040)$. In all other claims, the Chi-square test did not reveal differences between these two categories.

The assessment of knowledge about shelf life offered two options, namely, that UCB can be stored for an unlimited time or that stem cells quality decreases with time. Respondents mainly believed that storage time for UCB is not unlimited $(73.7 \%)$ and that stem cells lose quality with time $(69.9 \%)$. There was no significant difference between the categories of age, gender, level of education, health education, and parental status.

There was also no difference in opinion regarding the dangers of the UCB collection procedure between the categories of age, gender, level of education, health education, and parental status. It should be noted that $89.7 \%$ of the surveyed participants stated that the procedure does not represent a danger for either mother or child; the percentage of health professionals $(91.6 \%)$ opting for this answer was only slightly higher than that of nonprofessionals $(88.4 \%)$.

\section{Attitudes toward UCB banking}

More than one half of the respondents $(54.7 \%)$ absolutely accepted UCB banking as a relevant service, $22.0 \%$ accepted the same, $19.5 \%$ had no opinion, $2.3 \%$ refused, and $1.5 \%$ absolutely refused UCB banking as a relevant service. The significant differences in attitudes toward UCB banking were between the categories of gender, education, and health education (non-professionals/health professionals). There was no significant difference between the categories of age and children. Male respondents had more formulated opinions regarding UCB banking and a higher percentage of female respondents had no opinion regarding this issue. More female than male respondents absolutely accepted UCB banking. A larger number of respondents with postgraduate education absolutely accepted UCB banking than respondents from other education subgroups. UCB banking was categorized as absolutely accepted by $55.2 \%$ of non-professionals, and the figure was even higher for health professionals (59.6\%), as shown in Table 3.

The attitude toward UCB banking was also gauged by the respondents' willingness to pay for the service. Most respondents $(36.7 \%)$ were prepared to pay <EUR 1000, 16.6\% would pay between EUR 1000 and EUR 2000 (24.4\%), and 22.3\% of respondents were not willing to pay at all. There were significant differences among the having children categories and non-professionals/health professionals' categories regarding their willingness to pay for UCB banking. Most categories were prepared to pay <EUR 1000 EUR, as shown in Table 4. The majority of the respondents unwilling to pay had one or more children $(39.4 \%)$, followed by respondents with no children $(18.5 \%)$ and respondents expecting a child (17.6\%). More than one third of non-professionals (36.4\%) were prepared to pay $<$ EUR 1000 , while the majority of health professionals $(37.2 \%)$ were not willing to pay. 
Table 3: Attitudes toward umbilical cord blood banking $(n=408)$

\begin{tabular}{|c|c|c|c|c|c|c|c|}
\hline \multirow[t]{2}{*}{ Category } & \multicolumn{5}{|l|}{$\%(\mathrm{n})$} & \multirow[t]{2}{*}{$x^{2}$} & \multirow[t]{2}{*}{$p$-values } \\
\hline & Absolutely refuse & Refuse & No opinion & Accept & Absolutely accept & & \\
\hline \multicolumn{8}{|c|}{ 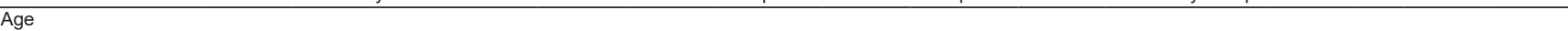 } \\
\hline $18-24$ & $1.8 \%(5)$ & $2.5 \%(7)$ & $18.2 \%(50)$ & $22.2 \%(61)$ & $55.3(152)$ & \multirow[t]{4}{*}{12.4} & \multirow[t]{4}{*}{0.410} \\
\hline $25-34$ & $1.0 \%(1)$ & $1.0 \%(1)$ & $17.6 \%(18)$ & $22.5 \%(23)$ & $57.9 \%(59)$ & & \\
\hline $35-44$ & 0 & 0 & $31.3 \%(5)$ & $12.5 \%(2)$ & $56.2 \%(9)$ & & \\
\hline $45-65$ & $6.7 \%(1)$ & $6.7 \%(1)$ & $33.3 \%(5)$ & 0 & $53.3 \%(8)$ & & \\
\hline \multicolumn{8}{|l|}{ Gender } \\
\hline Female & $0.9 \%(3)$ & $1.9 \%(6)$ & $21.2 \%(68)$ & $19.6 \%(63)$ & $56.4 \%(181)$ & \multirow[t]{2}{*}{11.1} & \multirow[t]{2}{*}{0.026} \\
\hline Male & $4.6 \%(4)$ & $3.4 \%(3)$ & $11.5 \%(68)$ & $26.4 \%(23)$ & $54.1 \%(47)$ & & \\
\hline \multicolumn{8}{|l|}{ Educational level } \\
\hline Secondary school & $1.2 \%(3)$ & $2.9 \%(7)$ & $19.7 \%(48)$ & $23.7 \%(58)$ & $52.7 \%(127)$ & \multirow[t]{3}{*}{15.8} & \multirow[t]{3}{*}{0.045} \\
\hline Graduate degree & $1.6 \%(2)$ & $1.6 \%(2)$ & $22.2 \%(28)$ & $19.0 \%(24)$ & $55.6 \%(70)$ & & \\
\hline Postgraduate degree & $5.4 \%(2)$ & 0 & $5.4 \%(2)$ & $10.8 \%(4)$ & $78.4 \%$ (29) & & \\
\hline \multicolumn{8}{|l|}{ Children } \\
\hline None & $1.5 \%(5)$ & $2.5 \%(8)$ & $17.8 \%(58)$ & $24.0 \%(78)$ & $54.2 \%(176)$ & \multirow[t]{3}{*}{10.7} & \multirow[t]{3}{*}{0.220} \\
\hline 1 or more children & $3.0 \%(2)$ & $1.5 \%(1)$ & $24.2 \%(16)$ & $10.6 \%(7)$ & $60.6 \%(40)$ & & \\
\hline Expecting a child & 0 & 0 & $23.5 \%(4)$ & $5.9 \%(1)^{\prime}$ & $70.6 \%(12)$ & & \\
\hline \multicolumn{8}{|l|}{ Health education } \\
\hline Non-professionals & $0.9 \%(3)$ & $2.3 \%(8)$ & $18.5 \%(64)$ & $23.1 \%(80)$ & $55.2 \%(191)$ & \multirow[t]{2}{*}{14.8} & \multirow[t]{2}{*}{0.005} \\
\hline Health professionals & $6.5 \%(4)$ & $1.6 \%(1)$ & $22.6 \%(14)$ & $9.7 \%(6)$ & $59.6 \%(37)$ & & \\
\hline
\end{tabular}

Table 4: Willingness to pay for umbilical cord blood banking services $(n=408)$

\begin{tabular}{|c|c|c|c|c|c|c|c|c|}
\hline \multirow[t]{2}{*}{ Category } & \multicolumn{6}{|l|}{$\%(n)$} & \multirow[t]{2}{*}{$x^{2}$} & \multirow[t]{2}{*}{ p-values } \\
\hline & $<1000 €$ & $1000-2000 €$ & $2000-3000 €$ & $3000-4000 €$ & $>4000 €$ & Not willing to pay & & \\
\hline \multicolumn{9}{|l|}{ Age } \\
\hline $18-24$ & $35.6 \%(98)$ & $26.9 \%(74)$ & $13.8 \%(38)$ & $4.7 \%(13)$ & $1.5 \%(4)$ & $17.5 \%(48)$ & \multirow[t]{4}{*}{22.4} & \multirow[t]{4}{*}{0.097} \\
\hline $25-34$ & $34.3 \%(35)$ & $23.5 \%(24)$ & $12.7 \%(13)$ & $2.0 \%(2)$ & $2.0 \%(2)$ & $25.5 \%(2)$ & & \\
\hline $35-44$ & $37.4 \%(6)$ & $6.3 \%(1)$ & $6.3 \%(1)$ & 0 & 0 & $50.0 \%(8)$ & & \\
\hline $45-65$ & $33.3 \%(5)$ & $13.3 \%(2)$ & 0 & $6.7 \%(1)$ & 0 & $46.7(7)$ & & \\
\hline \multicolumn{9}{|l|}{ Gender } \\
\hline Female & $36.8 \%(118)$ & $24.3 \%(78)$ & $12.1 \%(39)$ & $3.4 \%(11)$ & $0.9 \%(3)$ & $22.4 \%(72)$ & \multirow[t]{2}{*}{5.6} & \multirow[t]{2}{*}{0.347} \\
\hline Male & $29.9 \%(26)$ & $26.5 \%(23)$ & $14.9 \%(13)$ & $5.7 \%(5)$ & $3.4 \%$ (3) & $19.7 \%(17)$ & & \\
\hline \multicolumn{9}{|l|}{ Educational level } \\
\hline Secondary school & $34.7 \%(85)$ & $25.3 \%(62)$ & $14.7 \%(36)$ & $3.3(8)$ & $1.6 \%(4)$ & $20.4 \%(50)$ & \multirow[t]{3}{*}{5.5} & \multirow[t]{3}{*}{0.085} \\
\hline Graduate degree & $36.4 \%(46)$ & $24.6 \%(31)$ & $9.5 \%(12)$ & $4.0 \%(5)$ & $0.8 \%(1)$ & $24.5 \%(31)$ & & \\
\hline Postgraduate degree & $35.1 \%(13)$ & $21.7 \%(8)$ & $10.8 \%(4)$ & $8.1 \%(3)$ & $2.7 \%(1)$ & $21.6 \%(8)$ & & \\
\hline \multicolumn{9}{|l|}{ Children } \\
\hline None & $34.8 \%(113)$ & $26.7 \%(87)$ & $14.2 \%(46)$ & $4.0 \%(13)$ & $1.8 \%(6)$ & $18.5 \%(60)$ & \multirow[t]{3}{*}{20.2} & \multirow[t]{3}{*}{0.027} \\
\hline 1 or more children & $33.3 \%(22)$ & $18.2 \%(12)$ & $6.1 \%(4)$ & $3.0 \%(2)$ & 0 & $39.4 \%(26)$ & & \\
\hline Expecting a child & $52.9 \%(9)$ & $11.8 \%(2)$ & $11.8 \%(2)$ & $5.9 \%(1)$ & 0 & $17.6 \%(3)$ & & \\
\hline \multicolumn{9}{|l|}{ Health education } \\
\hline Non-professionals & $36.4 \%(126)$ & $26.4 \%(91)$ & $12.4 \%(43)$ & $4.0 \%(14)$ & $1.7 \%(6)$ & $19.1 \%(66)$ & \multirow[t]{2}{*}{12.2} & \multirow[t]{2}{*}{0.035} \\
\hline Health professionals & $29.0 \%(18)$ & $16.1 \%(10)$ & $14.5 \%(9)$ & $3.2 \%(2)$ & 0 & $37.2 \%(23)$ & & \\
\hline
\end{tabular}

\section{UCB banking option preferences}

When respondents were asked about their choice between public and private banks, more than one third $(34.6 \%)$ preferred private donations, $21.6 \%$ would recommend public storage and almost one half of the respondents had no opinion $(43.8 \%)$. There were significant differences between the categories of age, education, and children. A preference for public UCB banking was evident in younger respondents, male respondents, respondents with secondary school education, and respondents expecting a child. A preference for private UCB banking was evident in older respondents aged over 45 years, respondents with a postgraduate education and respondents with one or more children, as shown in Table 5.

\section{Perception of the prospects for UCB} in future medical applications among nonprofessionals and health professionals

The participants in the survey mainly think that it is likely that stem cells will be used widely for treatment in the next 25 years, that UCB will be routinely stored for all children and that they will be used for the treatment of neurological diseases and cancer, transplant rejections, cardiac failure, and Crohn's disease $(<15 \%$ of
Table 5: Umbilical cord blood banking option preferences ( $n=408)$

\begin{tabular}{|c|c|c|c|c|c|}
\hline \multirow[t]{2}{*}{ Category } & \multicolumn{3}{|l|}{$\%(n)$} & \multirow[t]{2}{*}{$x^{2}$} & \multirow[t]{2}{*}{$p$-values } \\
\hline & Public & Private & No opinion & & \\
\hline \multicolumn{6}{|l|}{ Age } \\
\hline $18-24$ & $36.7 \%(101)$ & $16.7 \%(46)$ & $46.6 \%(128)$ & \multirow[t]{4}{*}{16.7} & \multirow[t]{4}{*}{0.01} \\
\hline $25-34$ & $32.4 \%(33)$ & $28.4 \%(29)$ & $39.2 \%(40)$ & & \\
\hline $35-44$ & $25.0 \%(4)$ & $31.2 \%(5)$ & $43.8 \%(7)$ & & \\
\hline $45-65$ & $20.0 \%(3)$ & $53.3 \%(8)$ & $26.7 \%(4)$ & & \\
\hline \multicolumn{6}{|l|}{ Gender } \\
\hline Female & $33.6 \%(108)$ & $23.4 \%(75)$ & $43.0 \%(138)$ & \multirow[t]{2}{*}{2.9} & \multirow[t]{2}{*}{0.233} \\
\hline Male & $37.9 \%(33)$ & $14.9 \%(13)$ & $47.2 \%(41)$ & & \\
\hline \multicolumn{6}{|l|}{ Educational level } \\
\hline Secondary school & $36.4 \%(89)$ & $16.7 \%(41)$ & $46.9 \%(115)$ & \multirow[t]{3}{*}{15.4} & \multirow[t]{3}{*}{0.004} \\
\hline Graduate degree & $30.2 \%(38)$ & $25.4 \%(32)$ & $44.4 \%(56)$ & & \\
\hline Postgraduate degree & $37.9 \%(14)$ & $40.5 \%(15)$ & $21.6 \%(8)$ & & \\
\hline \multicolumn{6}{|l|}{ Children } \\
\hline None & $33.5 \%$ (109) & $18.2 \%(59)$ & $48.3 \%(157)$ & \multirow[t]{3}{*}{20.5} & \multirow[t]{3}{*}{0.001} \\
\hline 1 or more children & $33.3 \%(22)$ & $37.9 \%(25)$ & $28.8 \%(19)$ & & \\
\hline Expecting a child & $34.5 \%(141)$ & $21.6 \%(88)$ & $43.9 \%(179)$ & & \\
\hline \multicolumn{6}{|l|}{ Health education } \\
\hline Non-professionals & $35.3 \%(122)$ & $19.8 \%(68)$ & $45.1 \%(156)$ & \multirow[t]{2}{*}{5.0} & \multirow[t]{2}{*}{0.084} \\
\hline Health professionals & $30.6 \%(19)$ & $32.3 \%(20)$ & $37.1 \%(23)$ & & \\
\hline
\end{tabular}

respondents definitely disagree with these statements). Respondents see the greatest potential of cord blood stem cells for treatment of cancer diseases: Almost $39.5 \%$ definitely agree with this statement and only $2.6 \%$ of respondents disagree with it. Less confidence was expressed in the potential of stem cell technologies for the treatment of infertility and rejuvenation. However, there was no difference in opinion about the prospects for UCB stem cell technologies between the categories of age, gender, level of education, health education, and parental status. 


\section{Discussion}

An analysis of the online survey revealed no major differences between the laic and professional categories in terms of knowledge of the specific purpose and characteristics of UCB storage revealed. Health professionals were significantly more confident that storing UCB is not intended for cloning and that it is intended for the treatment of leukemia and other similar diseases. However, the level of knowledge about other purposes of UCB banking and the shelf life of cryopreserved UCB was the same in both groups. Furthermore, Peberdy et al. [5] identified that there was little focus placed on health professionals' knowledge of cord blood banking options, despite being identified by expectant parents as their preferred, key source of information. Other research on parents also found that their knowledge of cord blood use was mixed; many studies' participants did not correctly identify the uses [8].

There was also no significant difference between the non-professionals and health professionals' categories regarding knowledge of the safety of the UCB collection procedure. A significant percentage of the respondents stated that the UCB collection procedure is not dangerous for the mother or a newborn. Although this is consistent with literature, protocols emphasize the importance of delayed cord clamping [19], which has an influence on hematocrit and acid-base blood parameters after delivery [20].

An analysis of also showed that almost three quarters of the respondents had little awareness of UCB banking. Only a few of the respondents reported knowing at least one UCB bank. A subjective selfassessment shows their overall knowledge of UCB banking to be inadequate. These findings confirm other research that reports poor knowledge of UCB banking in general [5], [14]. Most of the respondents received information mainly from digital media, whereas only $15 \%$ received information from health professionals. This contrasts with the results of studies in other European countries (France, Germany, Italy, Spain, the UK, and Greece), where most respondents received information from health professionals [7], [9], [11], although similar results were found in Croatia [10]. Matijevic and Erjavec [10] assume that the inadequate information provided by health professionals is the consequence of a shortage of adequately educated midwives and nurses and specific programs to educate and inform pregnant women about UCB.

The quality of UCB and its efficacy for treatment largely depends on the number of clonogenic cells or CFU (colony forming units). It has been proven that post-thaw CFU was not influenced by storage time but was affected by some other factors [21]. Respondents in our survey, however, believed that storage time for UCB is not unlimited and that stem cells lose quality with time, demonstrating a lack of knowledge among both non-professionals and health professionals' categories.

The higher level of awareness and the subjective assessment of knowledge of UCB banking by health professionals as compared to non-professionals, on the one hand, and the relatively poor knowledge of UCB banking in general on the other, may be explained by the fact that health professionals acquire a better general knowledge about UCB through their education than through specific professional fields within the health sector (e.g., obstetrics, transplantation).

The majority of respondents expressed a positive attitude toward UCB banking and absolutely accepted or accepted UCB banking as a relevant service. However, more than one third of respondents were prepared to pay <EUR 1000, which is below the current rate for autologous UCB banking services, and $22.3 \%$ of respondents were not willing to pay for this service at all. Thus, only about $40 \%$ would be willing to pay more than EUR 1,000, which is relevant for different bio banking services in private biobanks. The study revealed a prevalent preference for private UCB banking, which is in line with the findings of the Greek study [9] but not with findings of other studies [7], [10], [11], which identified a prevalent preference for public UCB banking. One of the motives of parents to choose a private UCB bank is that $<1 / 2$ of the samples donated to the public UCB bank met the storage requirements for therapeutic use [22]. Donating UCB to a public bank, therefore, did not guarantee that the sample would be available for their children or relatives if needed.

Cell therapies are becoming an important platform technology in medicine; along with pharmaceuticals, biologics, and medical devices, they represent the fourth pillar of the healthcare system [23]. Moreover, the main obstacle of cord blood utilization for hematopoietic stem cell transplantation (i.e., insufficiently high total stem cell numbers because of limited cord blood volumes) seems to have been overcome by the development of efficient procedures for ex vivo expansion of primitive stem cells from the CD34+ fraction of cord blood [24]. Within this concept, UCB banking represents an important part of the infrastructure for the future development of cell therapies. Therefore, a comprehensive educational campaign with clear information about UCB banking aimed at achieving a higher level of consumer awareness and knowledge would be beneficial and should preferably be implemented by health professionals.

It should, however, be noted that the study focused only on certain segments of the general population, namely, a laic population of young and potential parents and health professionals. Future studies may include representative samples to identify the wider population's awareness and opinions regarding autologous UCB banking. The study included health professionals as a homogeneous category with health education. However, there may be differences in 
knowledge and attitudes between different categories of health professionals, for example, between doctors, nurses, or physiotherapists. The snowball sampling method also has some methodological limitations, as it does not allow the calculation of response rates and the results could be biased by some psychosocial characteristics of individuals, such as affinity to participate in online social platforms that were not tested.

Ethical aspects: The paper does not involve research on human subjects. The research work is based on a survey in which data were collected with voluntary participation of anonymous participants and publicly available data. The study protocol was reviewed and approved by the Research Committee.

\section{References}

1. Rubinstein P, Adamson JW, Stevens C. The placental/umbilical cord blood program of the New York blood center. A progress report. Ann N Y Acad Sci 1999;872:328-35. https://doi. org/10.1111/j.1749-6632.1999.tb08477.x

PMid:10372135

2. Hauskeller C, Beltrame L. The hybrid bioeconomy of umbilical cord blood banking: Re-examination the narrative of opposition between public and private services. BioSocieties. 2016;11:415-34. https://doi.org/10.1057/biosoc.2015.45

3. World Marrow Donor Association. Total Number of Donors and Cord Blood Units; 2020. World Marrow Donor Association. Available from: https://www.statistics.wmda.info. [Last accessed on 2020 Nov 23]

4. Mayani H, Wagner JE, Broxmeyer HE. Cord blood research, banking, and transplantation: Achievements, challenges, and perspectives. Bone Marrow Transplantation. 2020;55(1):48-61. https://doi.org/10.1038/s41409-019-0546-9

PMid:31089283

5. Peberdy L, Young J, Kearney L. Health care professionals knowledge, attitudes and practices relating to umbilical cord blood banking and donation: An integrative review. BMC Pregnancy Childbirth. 2016;16:81-100. https://doi.org/10.1186/ s12884-016-0863-6

PMid:27094796

6. O'Connor MA, Samuel G, Jordens CF, Kerridge IH. Umbilical cord blood banking: Beyond the public-private divide. J Law Med 2012;19(3):512-6

PMid:22558903

7. Katz G, Mills A, Garcia J, Hooper K, McGuckin C, PlatzA. Banking cord blood stem cells: Attitude and knowledge of pregnant women in five European countries. Transfusion. 2011;51(3):578-86. https://doi.org/10.1111/j.1537-2995.2010.02954.x PMid:21126259

8. Peberdy L, Young J, Massey DL, Kerney L. Parents' knowledge, awareness and attitudes of cord blood donation and banking options: An integrative review. BMC Pregnancy Childbirth. 2018;18(1):395-16. https://doi.org/10.1186/s12884-018-2024-6 PMid:30305052

9. Karagiorgou LZ, Pantazopoulou MN, Mainas NC, Beloukas AI, Kriebardis AG. Knowledge about umbilical cord blood banking among Greek citizens. Blood Transfusion.
2014;12(Suppl 1):S353-60.

PMid:24120604

10. Matijevic R, Erjavec K. Knowledge and attitudes among pregnant women and maternity staff about umbilical cord blood banking. Transfus Med. 2016;26(6):462-6. https://doi. org/10.1111/tme.12365

PMid:27714885

11. Screnci M, Murgi E, Pirre G, Valente E, Corona F, Girelli G. Donating umbilical cord blood to a public bank or storing it a private bank: Knowledge and preferences of blood donors and of pregnant woman. Blood Transfus. 2012;10(3):331-7. https:// doi.org/10.1016/j.bcmd.2015.12.010 PMid:22507856

12. Fox NS, Stevens $C$, Ciubotariu R, Rubinstein P, McCullough LB, Chervenak FA. Umbilical cord blood collection: Do patients really understand? J Perinat Med. 2007;35(4):314-21. https:// doi.org/10.1515/jpm.2007.084 PMid:17511596

13. Gupta V, Agarwal L, Ballal P, Pandey D. Cord blood banking: Antenatal care providers roles and responsibilities. Stem Cells Int. 2019;2:1-7. https://doi.org/10.1155/2019/3598404

14. Manegold G, Meyer-Monard S, Tichelli A, Granado C, Ho I, Troeger C. Controversies in hybrid banking: Attitudes of Swiss public umbilical cord blood donors toward private and public banking. Arch Gynecol Obstet. 2011;284(1):99-104. https://doi. org/10.1007/s00404-010-1607-x PMid:20658141

15. Martin I, Ireland H, Baldomero H, Passweg J. The survey on cellular and engineered tissue therapies in Europe in 2012. Tissue Engineering Part A. 2015;21(1-2):1-13. https://doi. org/10.1089/ten.tea.2014.0515

PMid:25425342

16. Gibson SG, Axler RE, Lemmens T. Transparency of biobank access in Canada. J Empir Res Hum Res Ethics. 2017; $12: 310-25$

17. Murphy J, Scott J, Kaufman D, Geller G, LeRoy L, Hudson K Public perspective on onformed consent for biobanking. Am J Public Health. 2009;99(12):2128-34. https://doi.org/10.2105/ ajph.2008.157099 PMid:19833988

18. Verlinden $\mathrm{M}$, Nys $\mathrm{H}$, Ectors $\mathrm{N}$, Huys I. Qualitative study on custodianship of human biological material and data stored in biobanks. BMC Med Ethics. 2016;17:1-10. https://doi. org/10.1186/s12910-016-0098-0 PMid:26926004

19. Pafumi C, Farina M, Maggi I, Russo A, Pernicone G, Giardina P, et al. Influence of the kind of delivery on umbilical cord blood collection. Haematologia. 2002;31(4):341-5. https://doi. org/10.1163/15685590160141378

PMid:12038518

20. Nudelman MJ, Goel K, Jegatheesan P, Song D, Huang A, Govindaswami B. Haematocrit in $<35$ weeks preterm infants who received at least 60 seconds of delayed cord clamping: A retrospective observational study. BMJ Paediatr Open. 2019;3(1):e000531. https://doi.org/10.1136/ bmjpo-2019-000531

PMid:31646196

21. Hussein E, De For T, Wagner J, Sumstad D, Brunstein CG, McKenna DH. Evaluation of post-thaw CFU-GM: Clinical utility and role in quality assessment of umbilical cord blood in patients receiving single unit transplant. Transfusion. 2020;60(1):144-54 https://doi.org/10.1111/trf.15592 PMid:31756003

22. Krašna $M$, Telebak $T$, Domanovič $D$. Analysis of cord blood units donated to the Slovenian cord blood bank. Zdr Vestnik. 
2009;78:451-5

23. Mason C, Dunnill P. Assessing the value of autologous and allogeneic cells for regenerative medicine. Regener Med. 2009;4(6):835-53. https://doi.org/10.2217/rme.09.64 PMid: 19903003

24. Lapostolle V, Chevaleyre J, Duchez P, Rodriguez L,
Vlaski-Lafarge M, Sandvig I, et al. Repopulating hematopoietic stem cells from steady-state blood before and after ex vivo culture are enriched in $\mathrm{CD}_{3} 4^{+} \mathrm{CD} 133^{+} \mathrm{CXCR}_{4}$ low fraction. Haematologica. 2018;103(10):1604-15. https://doi.org/10.3324/ haematol.2017.183962

PMid:29858385 